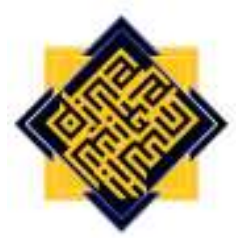

\title{
The Kiai's Cultural Strategy in Shaping the Religious Culture of the Community of Temboro Magetan Village, East Java
}

\author{
Zainal Arifin \\ UIN Sunan Kalijaga Yogyakarta, Indonesia \\ e-mail:zainal.arifin@uin-suka.ac.id \\ Maragustam \\ UIN Sunan Kalijaga Yogyakarta, Indonesia \\ e-mail:maragustam@uin-suka.ac.id \\ Muqowim \\ UIN Sunan Kalijaga Yogyakarta, Indonesia \\ e-mail:muqowim@uin-suka.ac.id \\ Hafidh 'Aziz \\ UIN Sunan Kalijaga Yogyakarta, Indonesia \\ e-mail:hafidh.aziz@uin-suka.ac.id
}

Abstract

Religious culture in the village of Temboro, which made it is known as "Kampung Madinah", certainly did not happen suddenly, but there was a process of formation and role of Kiai and Pesantren Al-Fatah. This study aims to analyze the Kiai's cultural strategy in developing a religious culture using a phenomenological approach and collects data through in-depth interviews, active participant observation, and documentation. The study results show that, firstly, ideological culture is the strategy of the Kiai in shaping the religious culture of the Temboro community. Secondly, the ideological culture of the Tablighi Jamaat has an impact on changing the five religious cultures of the Temboro community, namely: (1) ideological faith, (2) normative Islam, (3) Sufistic religious experience, (4) moderate-textual religious knowledge, (5) Maqami-intiqali practice.

Keywords: Cultural Strategy, Kiai, Religious Culture, Tablighi Jamaat, Temboro 
Zainal Arifin et al.

\section{A. Introduction}

Historically, the transformation of Temboro into a religious tourism village began with the establishment of the Pesantren al-Fatah in the $20^{\text {th }}$ century by Kiai Siddiq (189o1950) (Suparta, 2009). In 1984, the leadership relay was replaced by his son named $\mathrm{KH}$ Mahmud. There was a change in the orientation of pesantren education from Salafiyah NU system to the Salafiyah Tablighi Jamaat (Suparta, 2009). Tablighi Jamaat was founded by Muhammad Ilyas al-Kandhlawi (1885-1994), a Deoband alumnus in 1927 Mewat south Delhi India (Ali \& Amin, 2020). After this, the Pesantren al-Fatah became center of the largest Tablighi Jamaat movement in East Java, based on pesantren (Arifin, 2017). Moreover, Tablighi Jamaat is the largest transnational Islamic movement in the world (Mamun, 2019).

The naming of Temboro Village with "Kampung Medina" is an effort to build a village (village) order that tries to imitate the Medina order at the time of the Prophet Muhammad (Arifin, 2017; Awabien, 2020) whose daily activities are centered on the mosque. It is known that after moving to Medina (hijrah), there were three activities carried out by the Prophet, namely building mosques, taking time for mosques, and making mosque practices (Anonim, n.d.).

The religious activities of the Temboro people are influenced by the ideology of the Tablighi Jamaat, which is taught by the kiai of the Pesantren al-Fatah, who is also the Amir (leader) of this movement (Arifin et al., 2021). The center of religious activities is in the Trangkil Mosque belonging to pesantren. Every Friday night, the kiai holds a recitation (ijtima') which students, the Temboro community attend, and followers of the Tablighi Jamaat, both from within the country and abroad (Machmudi \& Ardhani, 2020). The concept of Ijtima' is to gather as many new members as possible and invite them along with the old members to perform khuruj (Ahmad, 2011).

The study of Tablighi Jamaat in Temboro, generally discusses ideological aspects and religious movements (Agha, 2015; Ali \& Amin, 2020; Aziz, 2004; Bustamam-Ahmad, 2008; Ma'mun, Huda et al., 2020), also related to amaliyah that characterizes Tablighi Jamaat such as khuruj and Masturah (Arifin et al., 2021; Machmudi \& Ardhani, 2020; Manshur, 2010). Several studies also examine the authority and leadership of Kiai and Nyai from the perspective of the Tablighi Jamaat (Arifin, 2017; Arifin \& Rohmah, 2019; Machmudi \& Ardhani, 2020; Nadlifah et al., 2020). Meanwhile, the influence of Tablighi jamaat ideology and the authority and leadership of the Kiai on changes in community culture has not been depth studied.

This study wants to analyze how the kiai's cultural strategy shapes the religious culture of the people of Temboro village located in Magetan Regency, East Java. The change in the religious culture of the Temboro community occurred after the al-Fatah Islamic Boarding School followed the ideology of the Tablighi Jamaat. This congregation came to Temboro around 1984 when groups from Pakistan and India came to al-Fatah boarding school (Suparta, 2009). There was a change in people's understanding of the importance of studying religion and forming an atmosphere of religious learning (Ghani, 2016). As researched by Benny Baskara in the Bajo community that the Tablighi Jamaat 
movement has changed the religious behavior of the people who are more orthodox (puritan) and fatalism (Baskara, 2020).

\section{B. Literature Review}

This study uses two theories: cultural strategies and religious (religious) dimensions-first, the cultural strategy. Peursen divides the three stages of human culture, namely: mythical, ontological, and functional (Peursen, 1988). Meanwhile, according to Kuntowijoyo, there are three human knowledge systems: myth, ideology, and science (Kuntowijoyo, 2001, 2006). Usman developed van Peursen \& Kuntowijoyo's theory into four types of awareness in Muslim society: jahiliyyah, diniyyah, 'ilmiyyah, and hanifiyyah (Usman, 2013).

This study uses the theory of culture in Islamic thought presented by Al-Jabiri, namely: Bayani, Burhani, and Irfani. Walid Harmaneh, in his introduction, said that in 1980, al-Jabiri published several articles that had been presented at various conferences on Islamic philosophers. Al-Jabiri's works are Nah\}nu wa al-Turas\}, two years later, he published a book on contemporary Arabic thought, al-Khit\}ab al-'Arabi al-Mu'as\}ir: Dirasah Tahliliyyah Naqdi\}yyah (Contemporary Arabic Discourse: Critical and Analytical Studies). This book was followed by three volumes of al-Jabiri's magnum opus entitled: Naqd al-'Aql al-'Arabi (Criticism of Arabic Reason) published in 1984, 1986, and 1990. Three volumes of Naqd al-'Aql al-'Arabi are: (1) Takwin al-'Aql al-'Arabi, (2) Bunyah al'Aql al-'Arabi, and (3) 'Aql as-Siyasi al-'Arabi (Mohammed 'Abed al-Jabiri, 1999).

In his two books, Takwin al-'Aql al-'Arabi and Bunyah al-'Aql al-'Arabi, al-Jabiri explains a lot about the three Arab cultures in understanding Islam, namely bayani, 'irfa ni, and burhani. Bayani culture is a system of thought that uses the Qur'an, hadith, ijma' and qiyas as a primary source of understanding (Widodo, 2007). For example, the opinion of Imam Syafi'i quoted by al-Jabiri, "Someone It is not permissible to say something is lawful or unlawful unless it uses knowledge based on the Qur'an, Hadith, ijma' and qiyas." (Muhammad 'Abed al-Jabiri, 2009). Burhani in Arabic means al-hujjah al-fas jilah albayyinah (Muhammad 'Abed al-Jabiri, 1990), which emphasizes 'aqliyyah or empirical rational reasoning through experimental tests (Muhadjir, 2014). While the culture of 'Irfani in Arabic is the masdar of 'arafa. In lisan 'Arabic, al-'irfan means knowledge. The term al'irfan, according to Sufism experts, indicates the meaning of ma'rifah, which means kasyaf or inspiration (Muhammad 'Abed al-Jabiri, 1990). This irfan tradition is rooted in the deepest, authentic, fitri, h\}anafiyyah samh \}ah experience and is almost unspeakable by logic and is not revealed by language, which is referred to as (al-'ilm al-h\}ud\}u ry) (Abdullah, 2010).

Second, the religious dimension in this study uses Stark and Glock, which consists of five aspects, namely belief (ideological), practice (ritualistic), experience (experiential), knowledge (intellectual), and practice (Consequential) (Reitsma et al., 2006; Saroglou, 2011). According to the Islamic perspective, these five dimensions are understood and can be equated with aqidah, sharia, and morals (Ancok \& Suroso, 2011). Subandi further understands the five dimensions of Stark and Glock in an Islamic perspective as follows: 
Zainal Arifin et al.

Table.1: Comparison of the Religious Dimensions of Stark and Glock and Islam (Subandi, 2013)

\begin{tabular}{lll}
\hline No & Dimensi Stark and Glock & Islam \\
\hline 1 & Religious belief (ideological) & Pillars of Faith (Rukun al-Iman) \\
\hline 2 & Religious practice (ritual) & Pillars of Islam (Rukun al-Islam) \\
\hline 3 & Religious feeling (experiential) & Sufism (Ihsan). \\
\hline 5 & Religious knowledge (intellectual) & Knowledge of fiqh, Tauhid, and Sufism \\
\hline 5 & Religious effect (consequential) & Deed (Amal) \\
\hline
\end{tabular}

\section{Research Methodology}

This research was conducted qualitatively with a religious phenomenology approach to understand and give a deeper meaning to a phenomenon or religious expressions (Dhavamony, 2010) as well as subjective religious facts, such as thoughts, feelings, ideas, emotions, intentions, and experiences of someone who expressed in words and deeds (Assegaf, 2007). The data collection technique was through documentation, in-depth interviews, and participant observation by participating in several religious activities at the al-Fatah Islamic Boarding Schools and Khuruj to participate in preaching in the community.

This research was conducted in 2014-2015 by conducting in-depth interviews with the Kiai of the al-Fatah Islamic boarding school, students, the Temboro community, and the Tablighi Jamaat activists from various regions who participated in Ijtima' at the Trangkil mosque. Triangulation was done to check data from various respondents' sources and techniques (Sugiyono, 2010). For example, the results of interviews with Kiai were cross-checked with observations or interviews with students or the community.

\section{Findings and Discussion}

\section{Ideology as Kiai's Cultural Strategy}

A significant change that became a milestone in the formation of the religious culture of the Temboro community was the change in the ideology of the pesantren from a pesantren based on the ideology of Nahdlatul Ulama (NU) to become the Tablighi Jamaat. The Kiai's decision to change the ideological basis of the Temboro pesantren is undoubtedly based on the ideology adopted by the Kiai, which is then applied to the education system at the Pesantren al-Fatah Temboro.

The success of ideological change in the Pesantren al-Fatah cannot be separated from the figure and authority of the Kiai. Kiai is the central figure of change in pesantren who has power and authority (Dhofier, 2011) which comes from a combination of pesantren education traditions and charisma (Rohmaniyah \& Woodward, 2012; Sukamto, 1999). The charisma of the Kiai can be obtained both given because it has genealogical ties and the process of engineering through spiritual mastery accompanied by morality, pious personality, and helping the community (Rozaki, 2004). 
Charismatic authority comes from the influence (emotional) of one's personality (Weber, 1968), characterized by obedience, not to rules or traditions (Turner, 1974). This charisma is related to the spiritual quality of the leader (Nadlifah et al., 2020), which encourages individual belief and trust (Karim, 2009). The charismatic leadership of the Kiai encourages people to obey and not oppose it because it can hinder blessings and cause kualat (Budiwiranto, 2009).

Ideology as a cultural strategy is interpreted as the Kiai's effort in influencing the Temboro community with an ideological approach or in Usman's language as diniyyah, namely awareness that emphasizes the spirit and quality of high and correct diversity (Usman, 2013). One of the hallmarks of Kiai leadership is having an ideological network (Muttaqin, 2020), and the dominant ideology developed by the Pesantren al-Fatah is the Tablighi Jamaat.

The authority and charisma of the Kiai in the Pesantren al-Fatah are evident in changing the ideological basis of Nahdlatul Ulama (NU) to the Tablighi Jamaat. Change is also Kiai's strategy to shape the religious culture of the Temboro community. This cultural transmission process occurs from the boarding school's classroom through the educational process; there is a transformation of the pesantren culture. This religious culture intersects with the surrounding community so that this pesantren's religious culture is also transferred to the community around the Pesantren al-Fatah.

\section{The Impact of the Ideological Culture of the Tablighi Jamaat on Changes in the Religious Culture of the Temboro Society}

The ideological culture of the Tablighi Jamaat that developed at the Pesantren alFatah had an impact on changing the religious culture for the Temboro community, namely: (1) ideological faith, (2) Normative Islam, (3) Sufistic religious experience, (4) moderate-textual religious knowledge, and (5) the practice of Maqami-Intiqali.

\section{a. Culture of Ideological Faith}

The Tablighi Jamaat is a faith movement (Ma'mun et al., 2020). As stated by Maulana llyas, the initiator of the Tablighi Jamaat that "This movement is a movement solely to renew and perfect faith."(A. A. As-Sirbuny, 2010). The purpose of this ideological faith is faith that is based on the ideological doctrines of the Tablighi Jamaat through bayan (religious lectures) delivered in mosques as well as during khuruj fi sabilillah activities (observation, February 5,2015 ). The sources of the books that are used as references are HJayah al-Sah\}abah (The Life of the Companions) by Maulana Muhammad Yusuf alKandahlawi, Fadhail al-Sahabah (The virtue of the Companions), and the Book of Fadhail al-A 'mal (Book of the Virtue of Charity) by Maulana Muhammad Zakaria al-Kandahlawi, and so on.

Ideological faith is always fostered through khuruj fi sabilillah activities. This activity is a form of practicing faith and an exercise in teaching faith to the community or learning by doing. The cultivation of ideological faith is influenced by the ideological doctrines of the Tablighi Jamaat. For example, it can be seen from KH Umar Fatahillah's lecture that "... 
Zainal Arifin et al.

Allah's commands do not have to be digested by reason, but must be obeyed. Religion is not reason but obeyed, if obeyed, then Allah will provide sustenance unexpectedly..." (Observation, March 3, 2015)

\section{b. Culture of Normative Islam}

Religious practice is related to ritual. In Islam, this dimension is included in the pillars of Islam that every Muslim must carry out. The cultural practice of the Temboro people's religion tends to be textual-normative, evidenced by how to understand religion and dress. For example, male residents usually wear a robe, turban, cingkrang pants, and maintain a long beard, while women wear a veil (purdah) and dark robes (black or brown). When entering the village of Temboro, many billboards invite Muslims to dress, behave Islamically, maintain cleanliness, and write calligraphy on every street corner and house (Observation 2014-2015)

This normative-textual Islamic practice culture in the Temboro community is influenced by the ideology of the Tablighi Jamaat, which tends to understand Islam literally (Aziz, 2004). However, the birth of the Pesantren al-Fatah is based on the NU ideology, which until now still teaches the classical books of the Shafi'i school of thought. In contrast, the origin of the Tablighi Jamaat is the Hanafi school because Maulana Ilyas, the founder of the Tablighi Jamaat, is an alumnus of Darul Ulum Deoband. The madzhab adopted by Deoband is Hanafi (Agha, 2015).

\section{c. Culture of Sufistic Religious Experience}

Religious experience in the Islamic tradition is related to the dimension of Ihsan, which emphasizes appreciation in religion. The religious experience of the Temboro people tends to a Sufistic culture can be seen from the khuruj activities in mosques carried out by the students and the Temboro community (interview with Lutfi al-Hasyimi, January 16, 2015). There are four main activities in khuruj: worship-remembrance (dzikir), da'wah, ta'lim, and khidmah (social services).

Many Tablighi Jamaat followers experience a change in character when participating in khuruj activities. For example, one member of the congregation admitted that there was a change in his character for the better; his life was more focused because he had a purpose and a passion for learning religion. (interview with Dadang, September 27, 2015).

The people of Temboro experienced an increase in worship practices, such as; praying five times in congregation, increasing public knowledge about religion, people's behavior being more religious, and Muslim women wearing Islamic clothes and wearing purdah (veil). The majority of Temboro people send their children to the Pesantren alFatah, and many Temboro people memorize the Qur'an and hadith (interview with $\mathrm{M}$. Syafi'i, January 2, 2015)

This phenomenon of character change is called religious transformation, which is the process of changing religious orientation from ordinary religious life to mystical religious life or from being religious to ordinary people (abangan) to being more religious and obedient in practicing religion (Subandi, 2009). 
The culture of the Sufistic religious experience of the Temboro community is also supported by the Naqasyabandiyah-Khalidiyah tarekat tradition, which was implemented at the al-Fatah Islamic Boarding School before the arrival of the Tablighi Jamaat ideology. The pioneering period of the Pesantren al-Fatah during the time of Kiai Shidiq (1890-1950), the model for the study was in the form of the Naqsyabandiyah tarekat, which is still being continued until now, for example, the Kiai used to give diplomas to his students, there were also certificates of hirzi (protection) verses to be guarded by Allah is born and inside, and so on (interview with Abdur Rouf, 15 January 2015)

In addition, the Tablighi Jamaat is a Sufism-Islamic-traditional revivalist movement (Ma'mun et al., 2020). Maulana llyas (1885-1944) is a Sufi figure who combines three models of a Muslim's life, namely Sufism, fundamental Islam, and the life of the Prophet Muhammad. The life of the Sufi M. Ilyas was influenced by the Naqsyabandiyah and Chistiyyah orders (Bustamam-Ahmad, 2008), although he did not use this tarekat theory in the obligatory practice for Tabligi. According to as-Sirbuny, "although Shaykh llyas and Shaykh In'amul Hasan (the grandson of Shaykh llyas) are Sufis, this da'wah effort does not follow Sufi theories." (As-Sirbuny, 2010).

\section{d. Culture of Textual-Moderate Religious Knowledge}

Tablighi Jamaat is one of the Sunni Islamic communities (Burhani, 2020) that preaches religious messages peacefully or peaceful fundamentalist (Aziz, 2004). This community concentrates on individual moral reform (Hasan, 2008) and is limited to the practice of sharia in matters of ritual, dress, and does not have a global political agenda, hence the name "traditionalists." (Metcalf, n.d.).

The Tablighi Jamaat's ideological pattern influences the culture of religious knowledge of the Temboro community, which tends to be textual-moderate. In that sense, religion is literally in understanding the texts of the Our'an and hadith, but being moderate with differences of opinion, evidenced by the existence of the ushul da'wah of the Tablighi Jamaat, which prohibits discussing politics, khilafiyah (differences) of madhhabs), community disgrace, and social status (al-Kandhalawi, 2008). The books that support the strengthening of religious knowledge from the perspective of the Tablighi Jamaat are as follows:

Table. 2: Tablighi Jamaat Ideology Books

\begin{tabular}{llll}
\hline No & Nama Kitab & Pengarang & Isi Kitab \\
\hline 1 & $\begin{array}{l}\text { Kitab Fadail } \\
\text { al-A'mal }\end{array}$ & $\begin{array}{l}\text { Maulana } \\
\text { Muhammad Zakaria } \\
\text { al-Kandahlawi }\end{array}$ & $\begin{array}{l}\text { It contains stories of the companions of the } \\
\text { Prophet, the virtues of prayer, tabligh, } \\
\text { remembrance, al-Qur'an, Ramadan, and how to } \\
\text { improve the decline of the people (al- } \\
\text { Kandahlawi, 2011). }\end{array}$ \\
\hline $2 \quad \begin{array}{lll}\text { Muntakhab } \\
\text { al- } \text { Ahadis\} }\end{array}$ & $\begin{array}{l}\text { Syaikh Maulana } \\
\text { Muhammad Yusuf } \\
\text { al-Kandahlawi } \\
\text { disusun kembali } \\
\text { oleh Syaikh Maulana } \\
\text { Muhammad Sa'ad }\end{array}$ & $\begin{array}{l}\text { contains the sentence thayyibah, prayer, } \\
\text { knowledge and remembrance, ikram al-muslimin, } \\
\text { sincere, da'wah and tabligh, and leaving things } \\
\text { that are not useful (Al-Kandahlawi, 2007). }\end{array}$ \\
& &
\end{tabular}

Dinamika Ilmu, Volume 21(2), 2021 
Zainal Arifin et al.

\begin{tabular}{llll}
\hline & & al-Kandahlawi & \\
\hline 3 & $\begin{array}{l}\text { Fadail } \\
\text { al-Sadaqat }\end{array}$ & $\begin{array}{l}\text { Maulana } \\
\text { Muhammad Zakaria } \\
\text { al-Kandahlawi }\end{array}$ & $\begin{array}{l}\text { contains the virtues of infaq of property, } \\
\text { reproaches of stingy attitude, friendship, the } \\
\text { virtue of zakat, zuhud attitude, qana'ah, and not } \\
\text { begging, and stories of zuhud experts and } \\
\text { philanthropists (al-Kandahlawi, 2006). }\end{array}$ \\
\hline 4 & $\begin{array}{l}\text { H\}ayahal- } \\
\text { Sahabah }\end{array}$ & $\begin{array}{l}\text { Maulana } \\
\text { Muhammad Yusuf } \\
\text { al-Kandahlawi }\end{array}$ & $\begin{array}{l}\text { Contains stories of the lives of the companions of } \\
\text { the Prophet, preaching to Allah swt. and His } \\
\text { messenger, allegiance, patience in the face of } \\
\text { suffering in the way of Allah, migration, nusrah, } \\
\text { and jihad fi sabilillah (Al-Kandahlawi, 2008). }\end{array}$ \\
\hline $5 \quad \begin{array}{l}\text { Fadilah Haji } \\
\text { Ibadah Haji \& } \\
\text { Umrah }\end{array}$ & $\begin{array}{l}\text { Maulana } \\
\text { Muhammad Zakaria } \\
\text { al-Kandahlawi }\end{array}$ & $\begin{array}{l}\text { Contains the pilgrimage and the virtues of Mecca } \\
\text { and Medina (al-Kandahlawi, 2008). }\end{array}$ \\
\hline
\end{tabular}

The moderation attitude of the Temboro people can be seen from their acceptance of other Sunni Islamic groups, which can be seen from preaching, which avoids the khilafiyah of madhhab but only invites the community to prosper the mosque. Thus, it can be concluded that the religious behavior of the Temboro people is exclusive for themselves (the group) but moderate for other (Sunni Islam) groups; this is the culture of textualmoderate religious knowledge that is influenced by the ideology of the Tablighi Jamaat.

\section{e. Culture of Maqami and Intiqali Practices}

The fifth change in religious culture is the practice of Maqami and Intiqali. These two practices impact the participation of the Temboro community with the Jamaah Tablighi ideology developed by the Pesantren al-Fatah. The word Maqami comes from the root word qama-yaqumu-qauman-al-maqam. The word al-maqam can be interpreted as a place, position, position, and situation (Munawir, 1997). The practice of Maqami in the Tablighi Jamaat tradition is carried out in the mosque where they each live by reviving four practices: remembrance (dzikir) and worship, ta'lim (teaching and learning), da'wah, and khidmah (service). (Interview with KH Imdad, January 16, 2015). Meanwhile, if these four practices are carried out outside their place of residence, they are called Intiqali practices, which in language means to move (out) (Munawir, 1997) or also called khuruj fi sabilillah (out in the way of Allah).

Of these four practices, one practice is community service (social), namely: khidmah (service); this can be seen from the people of Temboro, which is open to outsiders. Guests who attend the Temboro mosques are provided with a place to rest, drinking water, and a place to cook, and some even provide free food or drink. For worshipers who are khuruj (practice Intiqali), then other pilgrims whose husbands are not khuruj should provide necessities for wives left behind by their husbands (Observation, 2014-2015)

This Maqami and Intiqali practice of practice is a form of religious practice due to following the ideology of the Tablighi Jamaat. The practice of Intiqali in the form of khuruj to preach in the society, several stages must be passed as follows: 
Table.2: The stages in the da'wah effort (Anonim, n.d.)

\begin{tabular}{|c|c|c|c|}
\hline No & $\begin{array}{l}\text { Basic Stage } \\
\text { (10\% nisab age) }\end{array}$ & $\begin{array}{l}\text { Intermediate Stage } \\
\text { (1/3 nisab age) }\end{array}$ & $\begin{array}{l}\text { High Stage } \\
\text { (lifetime) }\end{array}$ \\
\hline 1 & 2.5 hours daily & 8 hours every day & \multirow{4}{*}{$\begin{array}{l}\text { Wealth, time, and self } \\
\text { are ready to be } \\
\text { discussed (in } d a^{\prime} \text { wah } \\
\text { efforts) }\end{array}$} \\
\hline 2 & 3 days every month & 10 days every month & \\
\hline 3 & 40 days every year & 4 months every year & \\
\hline 4 & 4 months for life & 1 year for life & \\
\hline
\end{tabular}

The practice of Intiqali (khuruj fi sabilillh) is the hallmark of the Tablighi Jamaat's da'wah model that distinguishes it from other Islamic organizations. In this activity, the congregation can follow the stages of preaching (3 days, 40 days, 4 months) by preaching around from mosque to mosque, both domestically and abroad. This da'wah model is believed by the Tablighi (followers of the Tablighi Jamaat) as da'wah 'ala mnhaj annubuwah (Arifin \& Rohmah, 2019), namely preaching by visiting people in the congregation. (interview with Dadang, 27 September 2015).

Intiqali practice for husbands and wives of the Tablighi Jamaat is called Masthurah, an effort to revive religious practices that are carried out secretly (Masturah) in the house so that the house functions as a mosque. Masturoh program activities such as majlis taklim, congregational prayers, remembrance, reading the Qur'an, and so on (Manshur, 2010). Masturoh's goal is to prepare wives to become mu'allimah and muta'alimah, daiyah, and a'bidah (Arifin et al., 2021).

Masturoh is a da'wah activity carried out by husband and wife. During Masturoh, the husbands live in the mosque while the wives stay at the homes of fellow Tablighi Jamaat members (Siddiqi, 2018). For the Tablighi Jamaat family, building a family must be based on religion, and the household is an important means for wives to be involved in strengthening family faith (Agha, 2015), namely through Masturoh activities.

\section{E. Conclusion}

This research can be concluded that the cultural strategy of the kiai of the Pesantren al-Fatah in shaping the religious culture of the Temboro community is through the actualization of the ideology of the Tablighi Jamaat in the education process and the daily activities of the pesantren, which then spread to the Temboro village community. As a transnational Islamic movement with a fundamentalist-Sufi Islamic understanding style, Tablighi Jamaat influences the religious attitude of its followers, namely moderate. The moderation of the Tablighi Jamaat is seen in its peaceful preaching by visiting the community, avoiding differences among Sunni Islam, and not having a global political agenda.

The ideological culture developed by Kiai of the Pesantren al-Fatah also has an impact on changes in the religious culture of the community, namely: (1) ideological faith, (2) Normative Islam, (3) Sufistic religious experience, (4) moderate-textual religious knowledge, and (5) the practice of Maqami-Intiqali. This change in religious culture implies 
Zainal Arifin et al.

that Temboro is known as the "Kampung Medina" and "Religious Tourism Village," which is promoted by the Magetan Regency Government of East Java.

\section{BIBLIOGRAPHY}

Abdullah, M. A. (2010). Islamic Studies di Perguruan Tinggi Pendekatan IntegratifInterkonektif, cet. ke-2. Pustaka Pelajar.

Agha, A. (2015). Religious Discourse in Tablighi Jama'at: A Challenge to Female Sexuality? International Journal of Multicultural and Multireligious Understanding, 2(3), 1. https://doi.org/10.18415/IJMMU.V2/3.5

Ahmad, K. B. (2011). Faith on the Move: Inside of the ljtimā' of Jamā'ah Tablīgh in Pekan Baru. Studia Islamika, 18(3). https://doi.org/10.15408/sdi.v18i3.426

al-Jabiri, Mohammed 'Abed. (1999). Arab-Islamic Philosophy A Contemporary Critique, translated from the French by Aziz Abbassi. The Center for Middle Eastern Studies and The University of Texas at Austin USA.

al-Jabiri, Muhammad 'Abed. (1990). Bunyah al-'Aql al-'Araby, Dirasah Tahliliyah Naqdiyyah li-Nudumi al-Ma'rifah fi al-Tsaqafah al-'Arabiyyah, cet. ke-3. Markaz Dirasat al-Wihdah al-'Arabiyyah.

al-Jabiri, Muhammad 'Abed. (2009). Takwin al-'Aql al-Araby, cetakan kesepuluh. Markaz Dirasat al-Wihdah al-'Arabiyah.

Al-Kandahlawi, M. M. Y. (2007). Muntakhab Ahadis Dalil-dalil Pilihan Enam Sifat Utama, cetakan II, (terj.) ustadz Ali Mahfudzi. Ash-Shaff.

Al-Kandahlawi, M. M. Y. (2008). Kehidupan Para Sahabat, (terj.) oleh M. Mahfufun Ni'am Junaid. Yogyakarta: Ash-Shaff.

al-Kandahlawi, M. M. Z. (2006). Fadhilah Sedekah, cetakan III, (terj.) Ustadz Ali Mahfudzi. Ash-Shaff.

al-Kandahlawi, M. M. Z. (2008). Fadhilah Haji, Ibadah Haji \& Umrah (Menuju Haji yang Mabrur), (terj.) oleh Ali Mahfudzi. Ash-Shaff.

al-Kandahlawi, M. M. Z. (2011). Kitab Fadilah A'mal (terj.) Tim Penerjemah Masjid Jami' Kebon Jeruk Jakarta. Pustaka Ramadhan.

al-Kandhalawi, M. M. Y. (2008). Mudzakarah Enam Sifat \& Amalan Nurani, edisi revisi ke-2. Pustaka Ramadhan.

Ali, J. A., \& Amin, F. (2020). Jamaat-e-Islami and Tabligh Jamaat: A Comparative Study of Islamic Revivalist Movements. ICR Journal, 11(1). https://doi.org/10.52282/icr.v11i1.24

Ancok, D., \& Suroso, F. N. (2011). Psikologi Islami Solusi Islam atas Problem-problem Psikologi,cet. ke-8. Pustaka Pelajar.

Anonim. (n.d.). Mudzakarah Da'wah Usaha Rasulullah. Pustaka al-Barokah.

Arifin, Z. (2017). The Authority of Spiritual Leadership at Pesantren Temboro Based on Jamaah Tabligh Ideology. Jurnal Pendidikan Islam, 6(2), 265-292. https://doi.org/10.14421/jpi.2017.62.265-292

Arifin, Z., \& Rohmah, L. (2019). The Concept of Leadership of the Transnational Islamic Ideology Perspective and Responses to Democracy Practices in Indonesia. 
The Kiai's Cultural Strategy in Shaping the Religious Culture

AKADEMIKA: Jurnal Pemikiran Islam, 24(1), 213-232. https://doi.org/10.32332/akademika.v24i1.1474

Arifin, Z., Siddiqi, B. A., Hamdun, D., \& Rahmi, S. (2021). The Impact of Masturah Program on The Families of Tablighi Jamaat at Temboro Village in Indonesia. Nazhruna: Jurnal Pendidikan Islam, 4(1), 136-149. https://doi.org/10.31538/NZH.V4l1.1128

As-Sirbuny, A. A. (2010). Kupas Tuntas Jamaah Tabligh 1. Pustaka Nabawi.

As-Sirbuny, A. A. A. (2010). Kupas Tuntas Jamaah Tabligh 3. Pustaka Nabawi.

Assegaf, A. R. (2007). Desain Riset Sosial-Keagamaan Pendekatan Integratif-Interkonektif. CDIE dan Gama Media.

Awabien, M. R. (2020). Living Hadis di Kampung Madinah, Temboro, Magetan. Jurnal Living Hadis, 5(1). https://doi.org/10.14421/livinghadis.2020.2171

Aziz, A. (2004). The Jamaah Tabligh Movement in Indonesia: Peaceful Fundamentalist. Studia Islamika, 11(3). https://doi.org/10.15408/sdi.v11i3.596

Baskara, B. (2020). The expansion of jama'ah tabligh movement and its influence on the religious belief of the bajo people in south east sulawesi. Journal of Indonesian Islam, 14(2). https://doi.org/10.15642/JIIS.2020.14.2.519-540

Budiwiranto, B. (2009). Pesantren and Participatory Development: The Case of the Pesantren Maslakul Huda Of Kajen, Pati, Central Java. Journal of Indonesian Islam, 3(2), 267-296. https://doi.org/10.15642/JIIS.2009·3.2.267-296

Burhani, A. N. (2020). Comparing Tablighi Jamaat and Muhammadiyah Responses to Covid-19. ISEAS-Yusof Ishak Institute, 75(75).

Bustamam-Ahmad, K. (2008). The History of Jama'ah Tabligh in Southeast Asia: The Role of Islamic Sufism in Islamic Revival. Al-Jami'ah: Journal of Islamic Studies, 46(2), 353400. https://doi.org/10.14421/ajis.2008.462.353-400

Dhavamony, M. (2010). Fenomenologi Agama (terj.) oleh Kelompok Studi Agama "Driyarkara" (11th ed.). Kanisius.

Dhofier, Z. (2011). Tradisi Pesantren Studi tentang Pandangan Hidup Kiai dan Visinya Mengenai Masa Depan Indonesia (gth ed.). LP3ES.

Ghani, S. H. A. (2016). Membongkar Misteri Gerakan Sosial Islam (Studi Analisis Visi, Misi dan Fenomenologis Komunitas Jamaah Tabligh). JURNAL INDO-ISLAMIKA, 6(1), 5781. https://doi.org/10.15408/IDI.V6l1.14795

Hasan, N. (2008). Laskar Jihad, Islam, Militansi, dan Pencarian Identitas di Indonesia PascaOrde Baru, (terj.) oleh Hairus Salim. Jakarta: LP3ES Indonesia \& KITLV.

Karim, A. G. (2009). The Pesantren-Based Ruling Elite in Sumenep in the Post-New Order Indonesia. JOURNAL OF INDONESIAN ISLAM, 3(1), 97. https://doi.org/10.15642/JIIS.2009.3.1.97-121

Kuntowijoyo. (2001). Muslim Tanpa Masjid: Esai-esai Agama, Budaya, dan Politik dalam Bingkai Struknturalisme Trasendental. Mizan.

Kuntowijoyo. (2006). Islam Sebagai Ilmu Epistemologi, Metodologi, dan Etika. Tiara Wacana.

Ma'mun, S., Huda, M. C., Muhsin, I., Maifizar, A., \& Muhammad, Z. (2020). Jamaat tablighi and negotiation of identity in the global world. Opcion, 36(SpecialEdition26).

Dinamika Ilmu, Volume 21(2), 2021 
Zainal Arifin et al.

Machmudi, Y., \& Ardhani, P. K. (2020). The Role of Women in Islamic Propagation: A Case Study of Tablighi Jamaat's Nyai of Pesantren Al-Fatah, East Java, Indonesia. Journal of Asian Social Science Research, 2(2), 175-190. https://doi.org/10.15575/jassr.v2i2.27

Mamun, S. (2019). Tablighi Jamaat, An Islamic Revivalist Movement and Radicalism Issues. Islam Realitas: Journal of Islamic \& Social Studies, 5(2), 145-159. https://doi.org/10.30983/islam_realitas.v5i2.1098

Manshur, M. M. (2010). Keutamaan Masturoh Usaha Da'wah di Kalangan Wanita Sesuai Contoh Rasul, Shahabat \& Shahabiyah. Pustaka Ramadhan.

Metcalf, B. D. (n.d.). "Traditionalist "Islamic Activism: Deoband, Tablighis, and Talibs." Muhadjir, N. (2014). Filsafat Epistemologi, Nalar Naqliyyah dan Nalar Aqliyyah, Landasan Profetik, Nalar Bayani, Irfani, dan Burhani, Perkembangan Islam dan IPTEK. Rake Sarasin: Rake Sarasin.

Munawir, A. W. (1997). Kamus Al-Munawir Arab-Indonesia Lengkap, (Surabaya: Pustaka Progressif. Pustaka Progressif.

Muttaqin, I. (2020). Types and Characteristics of Kyai Leadership Within Pesantren. Dinamika Ilmu, 20(1). https://doi.org/10.21093/di.v2oi1.2446

Nadlifah, N., Arifin, Z., \& Rahmi, S. (2020). Charismatic-Visionary Leadership of Teungku in Developing The Role of Dayah Mudi Mesra Samalanga, Bireun, Aceh. Cendekia: Jurnal Kependidikan Dan Kemasyarakatan, 18(1), 139-154.

Peursen, C. A. van. (1988). Strategi Kebudayaan. Kanisius.

Reitsma, J., Scheepers, P., \& Grotenhuis, M. Te. (2006). Dimensions of individual religiosity and charity: Cross-national effect differences in European countries? Review of Religious Research.

Rohmaniyah, I., \& Woodward, M. (2012). Wahhabism, Identity, and Secular Ritual: Graduation at an Indonesian High School. Al-Jami'ah: Journal of Islamic Studies, 50(1), 119-145. https://doi.org/10.14421/ajis.2012.501.119-145

Rozaki, A. (2004). Menabur Karisma Menuai Kuasa, Kiprah Kiai dan Blater sebagai Rezim Kembar di Madura. Pustaka Marwa.

Saroglou, V. (2011). Believing, bonding, behaving, and belonging: The big four religious dimensions and cultural variation. Journal of Cross-Cultural Psychology, 42(8). https://doi.org/10.1177/0022022111412267

Siddiqi, B. (2018). Becoming 'Good Muslim' The Tablighi Jamaat in the UK and Bangladesh. Singapore: Springer.

Subandi, M. A. (2009). Psikologi Dzikir Studi Fenomenologi Pengalaman Transformasi Religius. Yogyakarta: Pustaka Pelajar.

Subandi, M. A. (2013). Psikologi Agama \& Kesehatan Mental. Pustaka Pelajar.

Sugiyono. (2010). Metode Penelitian Pendidikan Pendekatan Kuantitatif, Kualitatif, dan $R \& D$. Bandung: Alfabeta.

Sukamto. (1999). Kepemimpinan Kiai dalam Pesantren. LP3ES.

Suparta, M. (2009). Perubahan Orientasi Pondok Pesantren Salafiyah terhadap Perilaku Keagamaan Masyarakat. Jakarta: Asta Buana Sejahtera.

Turner, B. S. (1974). Weber and Islam, a Critical Study. Routledge \& Kegan Paul. 
Usman. (2013). Jenis Kesadaran/Paradigma Masyarakat Muslim. Pustaka Pelajar.

Weber, M. (1968). Economy and Society. Bedminter Press.

Widodo, S. A. (2007). "Nalar Bayani, 'Irfani, dan Burhani dan Implikasinya Terhadap Keilmuan Pesantren." Hermeneia Jurnal Kajian Islam Interdisipliner Pascasarjana UIN Sunan Kalijaga Yogyakarta, 6(1). 